\title{
Efektivitas Supervisi Akademik dalam Meningkatkan Kemampuan Guru Menggunakan Metode Contextual Teaching And Learning
}

\author{
Toha Machsun \\ STAI YPBWI Surabaya \\ Email: tohamachsun@gmail.com
}

\begin{abstract}
Abstrak
Penelitian ini bertujuan menganalisis efektivitas supervisi akademik dalam meningkatkan kinerja guru menggunakan metode Contextual Teaching and Learning (CTL) dalam proses pembelajaran di MTs Muhammadiyah 1 Gresik. Penelitian ini dilakukan pada semester genap tahun pelajaran 2018-2019. Subjek penelitian adalah beberapa guru MTs Muhammadiyah 1 Gresik yang diidentifikasi mengalami kesulitan dalam menggunakan metode CTL. Data dikumpulkan melalui tes kinerja guru sebelum dan setelah dilakukan supervisi klinis. Selanjutnya data tersebut dianalisis dengan pendekatan kuantitatif. Temuan penelitian menunjukkan bahwa penerapan supervisi akademik dengan pendekatan klinis cukup efektif. Hal ini ditandai dengan rata-rata nilai kinerja guru dalam mengelola program pembelajaran menggunakan metode CTL setelah dilakukan supervisi akademik dengan pendekatan klinis sebesar 77,1\%. Artinya, hasil tersebut telah melebihi batas minimal ketuntasan belajar kelas, yaitu nilai $75 \%$. Terdapat 28 guru dari 30 guru $(93,3 \%)$ yang telah dinyatakan tuntas dalam menggunakan metode belajar CTL dengan rata-rata nilai mencapai $75 \% / l e b i h$.
\end{abstract}

Kata Kunci: Supervisi Akademik, Pendekatan Klinis, Metode Contextual Teaching and Learning

\section{Pendahuluan}

Salah satu metode belajar yang termasuk inovatif dalam membangkitkan motivasi belajar siswa adalah metode belajar Contextual Teaching and Learning (CTL). Oleh karena itu, CTL perlu dibudayakan dalam proses pembelajaran di sekolah. Beberapa dasar pemikiran pentingnya penggunaan metode tersebut di antaranya selama ini pendidikan kita masih didominasi oleh pandangan bahwa pengetahuan sebagai perangkat fakta-fakta yang harus dihafal. Kelas masih berfokus pada guru sebagai sumber utama pengetahuan, kemudian ceramah menjadi pilihan utama strategi belajar. Untuk itu, diperlukan sebuah strategi belajar "baru" yang lebih memberdayakan siswa. Sebuah strategi 
belajar yang mendorong siswa mengkonstruksikan pengetahuan di benak mereka sendiri yaitu metode pembelajaran kontekstual yang dikenal dengan Contextual Teaching and Learning (CTL).

Contextual Teaching and Learning (CTL) merupakan sistem pembelajaran yang sesuai dengan kinerja otak, untuk membangun pola yang mewujudkan makna, dengan menghubungkan konten akademik dengan konteks kehidupan sehari-hari peserta didik. Penting untuk menerapkan agar informasi yang diterima adalah tidak hanya disimpan dalam memori jangka pendek, yang mudah dilupakan, tetapi dapat disimpan dalam jangka panjang memori, sehingga akan diterapkan dalam tugas pekerjaan. ${ }^{1}$ Penerapan CTL akan sangat membantu guru untuk menghubungkan mata pelajaran penting dengan situasi dunia nyata dan memotivasi siswa untuk membentuk hubungan antara pengetahuan dan menerapkannya dalam kehidupan sehari-hari sebagai anggota keluarga dan masyarakat.

Melalui landasan filosofi konstruktivisme, CTL diharapkan menjadi alternatif strategi belajar baru. Melalui strategi ini, siswa diharapkan belajar melalui "mengalami", bukan "menghafal". Pengetahuan dikembangkan untuk memenuhi kebutuhan yang selalu berkembang seiring dengan perkembangan budaya manusia. Pengetahuan bukan sederet fakta, konsep, atau norma-norma yang harus ditemukan. Bukan sesuatu yang terlepas dari ilmuwan. Manusia membangun pengetahuan sebagaimana yang Ia berikan makna atas pengalamanpengalaman mereka. Segala sesuatu yang kita ketahui kita dapat membuatnya. Sebagaimana dikemukakan Zahorik:

"Knowledge is constructed by humans. Knowledge is not a set of facts, concepts, or laws waiting to be discovered. Its is not something that exists independent of a knower. Humans create or construct knowledge as they attempt to bring meaning to their experience. Everything that we know, we have made." 2

Pada dasarnya, guru adalah bagian integral dari organisasi pendidikan di sekolah secara menyeluruh. Agar sebuah organisasi-termasuk organisasi pendidikan di sekolah-- mampu menghadapi perubahan dan ketidakpastian yang menjadi ciri kehidupan modern, Peter

${ }^{1}$ Surdin, "The Effect of Contextual Teaching and Learning (CTL) Models on learning outcomes of Social Sciences of the material of forms the face of the earth on Class VII of Junior High School", International Journal of Education and Research, Vol. 6, No. 3 (March 2018).

2 John A. Zahorik, Constructivist Teaching (Bloomingthon Indiana: Phi-Delta Kappa Educational Foundation, 1995), 98. 
Senge, ${ }^{3}$ mengingatkan perlunya mengembangkan sekolah sebagai sebuah organisasi pembelajar. Di antara karakter utama organisasi pembelajar adalah senantiasa mencermati perubahan internal dan eksternal yang diikuti dengan upaya penyesuaian diri dalam rangka mempertahankan eksistensinya. Syarat mutlak terciptanya organisasi pembelajar adalah terwujudnya masyarakat pembelajar di tubuh organisasi tersebut. Ini dapat dengan mudah difahami mengingat kinerja organisasi secara tidak langsung adalah produk kinerja kolektif semua unsurnya, termasuk Sumber Daya Guru. Oleh sebab itu guru secara individu maupun secara bersama-sama dengan masyarakat seprofesinya harus didorong untuk menjadi bagian dari organisasi pembelajar melalui keterlibatannya secara sadar dan sukarela serta terus menerus dalam berbagai kegiatan belajar guna mengembangkan profesionalismenya. Untuk itulah peran Peneliti, kepala madrasah, dan pemerhati guru sangat menentukan bagi peningkatan profesionalisme guru.

Keberadaan guru dalam sistem pendidikan nasional kita sangat penting, guru adalah pendidik profesional dengan tugas utama mendidik, mengajar, membimbing, mengarahkan, melatih, menilai, dan mengevaluasi peserta didik pada pendidikan anak usia dini jalur pendidikan formal, pendidikan dasar, dan pendidikan menengah. ${ }^{4}$ Guru merupakan sebutan dari istilah pendidik, yakni sosok manusia yang menempati posisi dan memegang peranan penting dalam pendidikan. Guru merupakan jabatan atau profesi yang memerlukan keahlian khusus sebagai guru. Pekerjaan ini tidak dapat dilakukan oleh orang yang tidak memiliki keahlian untuk melakukan kegiatan atau pekerjaan sebagai guru. Keahlian guru belum cukup hanya diperoleh dari lembaga pendidikan kependidikan yang Ia masuki sebelum menjadi guru (pre service trainning). Sebab, tuntutan kompetensi profesional guru terus meningkat seiring dengan tuntutan masyarakat akan mutu pendidikan. Kinerja guru dalam mengembangkan pembelajaran dengan kurikulum berbasis kompetensi (KBK) dan kinerja guru mengembangkan kurikulum tingkat satuan pendidikan (KTSP) dan kurikulum 2013 (K-13) belum diperoleh sebagian guru ketika Ia masih kuliah di lembaga pendidikan tenaga kependidikan. Oleh karena itu menjadi tugas dan tanggungjawab kepala madrasah, Peneliti madrasah, dan pemerhati karir guru untuk memberikan pembinaannya melalui program supervisi agar guru mampu

3 Peter Senge, et al., Schools That Learn: A Fifth Discipline Fieldbook for Educators, Parents, and Everyone Who Cares About Education (New York: Doubleday/Currency, 2000), 231.

${ }^{4}$ Pasal 1 ayat 1 UU No. 14 tahun 2005 tentang Guru dan Dosen.

El-Banat Vol. 9. No.2 (2019) 323 
mengembangkan program pembelajarannya sesuai prinsip-prinsip kurikulum yang berlaku di madrasah.

Beberapa studi di negara-negara berkembang menurut Indra Jati Sidi ${ }^{5}$ menunjukkan bahwa guru memberikan sumbangan terbesar, yakni $36 \%$ terhadap prestasi belajar siswa, manajemen 23\%, waktu belajar 23\%, dan sarana fisik $19 \%$. Temuan tersebut menunjukkan bahwa peran guru paling dominan dalam pembelajaran. Rendahnya profesionalisme guru berdasarkan pengamatan sehari-hari juga tercermin pada fenomena kinerja guru dalam penyusunan program pembelajaran, khususnya rencana pelaksanaan pembelajaran (RPP). Guru-guru MTs. Muhammadiyah 1 Gresik dalam menyusun RPP kebanyakan tidak menyusun sendiri melainkan tinggal menggunakan dari Musyawarah Guru Mata Pelajaran (MGMP). Bagaimana kreativitas guru dapat berkembang dalam menyusun program pembelajaran jika program pembelajaran tinggal menggunakan yang sudah jadi. Hal ini jelas bertentangan dengan kurikulum, baik KTSP maupun kurikulum 2013 yang menghendaki program pembelajaran disusun sesuai kebutuhan riil di setiap sekolah/madrasah. Oleh sebab itu, untuk memperoleh gambaran lengkap dan hasil yang valid, maka penelitian ini dilakukan.

\section{Supervisi Akademik dan Kualitas Pembelajaran}

Supervisi akademik menurut Sujana ${ }^{6}$ adalah menilai dan membina guru dalam rangka meningkatkan kualitas proses pembelajaran agar kompetensi peserta didik mencapai optimal. Dalam konteks penelitian ini bantuan yang dimaksud adalah bantuan dalam menggunakan metode CTL. Tujuan supervisi klinik adalah memperbaiki perilaku guru dalam proses belajar mengajar, terutama yang kronis secara aspek demi aspek dengan intensif sehingga mereka dapat mengajar dengan baik, untuk perilaku yang tidak kronis bisa diperbaiki dengan teknik supervisi lainnya.

Di lingkungan MTs. Muhammadiyah 1 Gresik telah diwajibkan kepada guru untuk menggunakan berbagai metode pembelajaran yang tergolong inovatif, termasuk metode $C T L$, namun sebagian besar guru masih saja mengalami kesulitan, baik dalam merumuskan RPP yang sesuai tuntutan metode yang dipilih, dalam melaksanakan pembelajaran,

5 Subijanto, "Profesi Guru Sebagai Profesi yang Menjanjikan Pasca Undangundang Guru dan Dosen", Jurnal Pendidikan dan Kebudayaan, No. 67, (Juli 2007): 702.

6 S. Sudjana, Manajemen Program Pendidikan (Bandung: Falah Production, 2008), 48. 
maupun dalam mengevaluasi hasil belajar. Untuk itulah penelitian ini dilakukan agar performansi guru dalam menggunakan metode CTL dapat meningkat yang dampaknya dapat meningkatkan motivasi belajar siswa dan akhirnya dapat meningkatkan prestasi belajar siswa.

Berdasarkan uraian di atas maka masalah penelitian ini adalah bagaimana: (1) kinerja guru dalam menggunakan metode CTL dalam proses pembelajaran di MTs. Muhammadiyah 1 Gresik pada semester genap tahun pelajaran 2018-2019 sebelum dilakukan supervisi klinis?; (2) program supervisi klinis bagi guru dalam menggunakan metode pembelajaran CTL; dan (3) bagaimana efektivitas supervisi klinis dalam meningkatkan kinerja guru menggunakan metode CTL tersebut?

Tujuan penelitian ini untuk mendeksripsikan: (1) kinerja guru dalam menggunakan metode CTL dalam proses pembelajaran di MTs. Muhammadiyah 1 Gresik pada semester genap tahun pelajaran 20182019 sebelum dilakukan supervisi klinis?; (2) program supervisi klinis bagi guru dalam menggunakan metode pembelajaran CTL; dan (3) efektivitas supervisi klinis dalam meningkatkan kinerja guru menggunakan metode CTL tersebut.

Penelitian ini cukup signifikan bagi peningkatan profesionalisme guru, baik secara teoritik maupun praktis. Secara teoritik, temuan penelitian ini dapat berkontribusi bagi pengembangan keilmuan, khususnya di bidang manajemen pendidikan. Secara praktis, diperoleh sebab temuan penelitian ini dapat digunakan sebagai masukan bagi para kepala MTs. Muhammadiyah 1 Gresik dan Peneliti guru MTs. dalam membina guru dengan pendekatan klinis, khususnya dalam menggunakan metode pembelajaran CTL. Program supervisi akademik dengan pendekatan klinis dapat dikembangkan dengan mempertimbangkan temuan penelitian ini dengan adaptasi di beberapa aspek yang diperlukan.

Metode Pembelajaran Contextual Teaching and Learning (CTL) menurut Komalasari ${ }^{7}$ mendefinisikan pembelajaran kontekstual adalah pembelajaran yang mengaitkan materi yang dipelajari dengan kehidupan nyata siswa sehari-hari, baik dalam lingkungan, keluarga, sekolah, masyarakat maupun warga negara dengan tujuan untuk menemukan makna materi tersebut bagi kehidupan. Suprijono ${ }^{8}$ mengemukakan CTL merupakan konsep yang membantu guru mengaitkan antara materi yang diajarkan dengan situasi dunia nyata dan mendorong peserta didik membuat hubungan antara pengetahuan yang dimiliki dengan penerapan

${ }^{7}$ Kokom Komalasari, Pembelajaran Kontekstual: Konsep dan Aplikasi (Bandung: Refika Aditama, 2010), 7.

8 Agus Suprijono, Cooperative Learning: Teori dan Aplikasi PAIKEM (Yogyakarta : Pustaka Pelajar, 2009), 79. 
dalam kehidupan mereka sebagai anggota keluarga dan masyarakat. Pengetahuan dan keterampilan siswa diperolah dari usaha siswa mengkonstruksikan sendiri pengetahuan dan keterampilan baru ketika ia belajar.

Nurhadi ${ }^{9}$ mengemukakan bahwa pembelajaran kontekstual terjadi apabila siswa menerapkan dan mengalami apa yang sedang diajarkan dengan mengacu pada masalah-masalah dunia nyata yang berhubungan dengan peran dan tanggung jawab mereka sebagai anggota keluarga, warga negara, siswa dan tenaga kerja. Sanjaya ${ }^{10}$ mendeskripsikan bahwa metode CTL adalah metode pembelajaran yang menekankan kepada proses keterlibatan siswa secara penuh untuk dapat menemukan materi yang dipelajari dan menghubungkannya dengan situasi kehidupan nyata sehingga mendorong siswa untuk dapat menerapkannya dalam kehidupan mereka. Berdasarkan beberapa kutipan di atas, dapat disimpulkan bahwa CTL adalah suatu pembelajaran yang mengaitkan antara materi dengan situasi dunia nyata yang saling terhubung dan terjadi disekitar siswa sehingga siswa lebih mudah dalam memahami materi yang dipelajari dan mengambil manfaatnya serta dapat menerapkannya dalam kehidupan.

Pembelajaran kontekstual memiliki beberapa karakteristik yang khas yang membedakan dengan pendekatan pembelajaran yang lain. Pembelajaran kontekstual mengembangkan level kognitif tingkat tinggi yang melatih peserta didik untuk berpikir kritis dan kreatif. Menurut Muslich ${ }^{11}$ bahwa karakteristik pembelajaran CTL: (1) Pembelajaran dilaksanakan dalam konteks autentik, yaitu pembelajaran yang diarahkan pada ketercapaian keterampilan dalam konteks kehidupan nyata atau pembelajaran yang dilaksanakan dalam lingkungan yang alamiah (learning in real life setting). (2) Pembelajaran memberikan kesempatan kepada siswa untuk mengerjakan tugas-tugas yang bermakna (meaningful learning); (3) Pembelajaran dilaksanakan dengan memberikan pengalaman bermakna kepada siswa (learning by doing); (4) Pembelajaran dilaksanakan melalui kerja kelompok, berdiskusi, saling mengoreksi antar teman (learning in a group); (5) Pembelajaran memberikan kesempatan untuk mencipatakan rasa kebersamaan, bekerja sama, saling memahami antar satu dengan yang lain secara mendalam (learning to know each other deeply); (6) Pembelajaran dilaksanakan secara aktif, kreatif, produktif, dan mementingkan kerja sama (learning to

${ }^{9}$ Mansur Muslich, KTSP: Pembelajaran Berbasis Kompetensi dan Kontekstual (Jakarta: Bumi Aksara, 2009), 41.

${ }^{10}$ Wina Sanjaya, Strategi Pembelajaran Berorientasi Standar Proses Pendidikan (Jakarta: Kencana Prenada Media Group, 2006), 109.

${ }^{11}$ Muslich. KTSP, 42. 
ask, to inquri, to work together); (7) Pembelajaran dilaksanakan dalam situasi yang menyenangkan (learning as an enjoy activity).

Berdasarkan definisi di atas dapat disimpulkan bahwa karakteristik pembelajaran CTL adalah pembelajaran dilaksanakan dalam konteks autentik dengan menggali pengetahuan siswa, memberikan tugas-tugas yang bermakna, membentuk kelompok untuk menciptakan kerjasama antar siswa, dan mencipatkan pembelajaran yang menyenangkan dengan memberikan pengalaman yang bermakna. Ada tiga hal yang harus dipahami dalam konsep CTL: Pertama, CTL menekankan proses pelibatan siswa untuk menemukan materi dan makna, sehingga proses pembelajarannya berorientasi langsung ke proses pengalaman. Proses pembelajaran dalam konteks CTL tidak mengharapkan siswa untuk menerima materi pelajaran saja, tetapi proses mencari dan menemukan pengetahuan mereka sendiri. Kedua, CTL mendorong siswa untuk menemukan hubungan antara materi yang dipelajari dan situasi kehidupan nyata, itu berarti bahwa siswa dituntut untuk menangkap hubungan antara pembelajaran pengalaman dan kehidupan nyata. Ini sangat penting, karena dengan dapat menghubungkan materi yang ditemukan kehidupan nyata, materi akan bermakna secara fungsional dan itu akan tertanam dalam memori siswa, jadi itu tidak akan mudah dilupakan. Ketiga, CTL mendorong siswa untuk menerapkannya dalam kehidupan, itu berarti bahwa CTL tidak hanya mengharapkan siswa untuk melakukannya memahami materi yang mereka pelajari, tetapi bagaimana materi pelajaran dapat mewarnai perilaku mereka kehidupan sehari-hari. Materi pelajaran dalam konteks CTL tidak boleh ditumpuk di otak dan kemudian dilupakan, tetapi sebagai ketentuan mereka dalam kehidupan sosial.

Trianto $^{12}$ mengemukakan bahwa pembelajaran CTL melibatkan tujuh komponen utama, yaitu (1) konstruktivisme (constructivism), (2) bertanya (questioning), (3) inkuiri (inquiry), (4) masyarakat belajar (learning community), (5) permodelan (modeling), (6) refleksi (reflection), dan (7) penilaian autentik (authentic assessment). Muslich ${ }^{13}$ menyatakan setiap komponen utama pembelajaran CTL mempunyai prinsip-prinsip dasar yang harus diperhatikan ketika akan menerapkannya dalam pembelajaran, yaitu: (1) Konstruktivisme (constructivism), pengetahuan dibangun sedikit demi sedikit melalui proses; (2) Bertanya (questioning), kegiatan guru mendorong, membimbing, dan menilai

12 Trianto, Mendesain Model Pembelajaran Inovatif Progresif (Surabaya: Kencana, 2009), 107.

${ }^{13}$ Mansur Muslich, Pendidikan Karakter: Menjawab Tantangan Krisis Multidimensional (Jakarta: Bumi Aksara, 2011), 44.

El-Banat Vol. 9. No.2 (2019) 327 
kemampuan berfikir siswa. Kegiatan bertanya penting untuk menggali informasi, mengkonfirmasi apa yang sudah diketahui, dan mengarahkan perhatian pada aspek yang belum diketahuinya; (3) Inkuiri (inquiry), pengetahuan dan keterampilan yang diperoleh siswa diharapkan bukan hasil mengingat seperangkat fakta-fakta, tetapi hasil dari menemukan sendiri; (4) Masyarakat Belajar (learning community), hasil belajar diperoleh dari kejasama dengan orang lain. Dalam praktiknya "masyarakat belajar" terwujud dalam pembentukan kelompok kecil, kelompok besar, mendatangkan ahli ke kelas, bekerja sama dengan kelas paralel, bekerja kelompok dengan kelas di atasnya, bekerja sama dengan masyarakat; (5) Permodelan (modeling), proses pembelajaran dengan memperagakan sesuatu contoh model nyata. Dalam penerapannya guru mencontohkan dengan menggunakan alat bantu; (6) Refleksi (reflection), upaya untuk melihat kembali, mengorganisasi kembali, menganalisis kembali, mengklarifikasi kembali, dan mengevaluasi hal-hal yang telah dipelajari; (7) Penilaian autentik (authentic assessment), upaya pengumpulan berbagai data yang bisa memberikan gambaran perkembangan belajar peserta didik. Dalam penilaian autentik ini, data dikumpulkan dari kegiatan nyata yang dikerjakan peserta didik pada saat melakukan pembelajaran meskipun dalam implementasinya kebanyakan guru menghadapi problematika, di antaranya: terlalu banyak aspek yang dinilai dan teknik yang digunakan sehingga memberatkan guru, ketersediaan waktu guru terbatas, karakteristik siswa yang kurang jujur, jumlah siswa di kelas yang masih banyak, dan individu guru yang kebanyakan enggan melakukan penilaian autentik. ${ }^{14}$

\section{Kinerja Guru dalam Menggunakan Metode CTL Sebelum Dilakukan Supervisi}

Pada hari pertama supervisi, yakni hari Sabtu tgl. 16 Maret 2019, dilakukan heregrestasi peserta supervisi kemudian penjelasan proses supervisi, dan pre test dokumen RPP yang telah dipersiapkan oleh masing-masing guru sesuai pemberitahuan peneliti kepada guru melalui kepala MTs. Muhammadiyah 1 Gresik. Kegiatan ini dilakukan sampai jam 15.00 WIB, untuk kemudian supervisi hari pertama ditutup dan dilanjutkan hari Sabtu tgl. 23 Maret 2019. Agenda acara supervisi pada hari kedua ini adalah pre test implementasi RPP dan evaluasi hasil belajar. Kelas dibagi empat, tiga kelas berisi 10 guru dan satu kelas berisi

14 Ma'ruf, "Problematika Guru dalam Implementasi Penilaian Autentik Pada Kurikulum 2013 di SD Al Muslim Waru Sidoarjo", Jurnal Pendidikan Dasar Nusantara, Vol. 5 (Juli 2019). 
kelas 9 guru. Secara bergantian di setiap kelas seorang guru diminta memerankan sebagai guru yang diminta untuk mengimplementasikan RPP yang sudah dibuatnya dan guru lainnya berperan sebagai siswa. Dalam praktek micro teaching ini setiap guru hanya diminta praktek membentuk kelompok, presentasi materi pelajaran, dan instruksi pemberian ulangan harian. Praktek diskusi kelompok dan diskusi kelas tidak perlu dilakukan. Namun untuk praktek analisis hasil ulangan harian, guru diberi pertanyaan oleh peneliti tentang cara menganalisis hasil ulangan harian sampai diketahui tingkat ketuntasan belajarnya berdasarkan data yang disiapkan peneliti. Oleh karena itu waktu untuk tiap-tiap guru maksimal hanya 30 menit. Dengan demikian alokasi waktu untuk pre-test ini cukup satu hari, mulai jam 09.00 WIB. s/d jam 16.00 WIB dengan istirahat 1 jam pada jam $12.00 \mathrm{WIB}$ s/d 13.00 WIB.

Mengingat guru peserta supervisi sebanyak 39 guru, maka dalam pre-test guru dibagi ke dalam 4 kelompok, oleh karena itu dibutuhkan pengamat kelas sebanyak 4 orang. Untuk ini peneliti meminta bantuan kepala madrasah, wakasek kurikulum, dan wakasek kesiswaan untuk membantunya menjadi penilai dokumen RPP dan pengamat proses pembelajaran dalam pre-test implementasi pembelajaran berbentuk micro teaching, serta menguji kemampuan guru dalam analisis hasil ulangan harian dengan data yang disiapkan peneliti.

Berdasarkan hasil pre-test diperoleh data sebagaimana tercantum pada Tabel 1.

Tabel 1:

Data Kinerja Guru Sebelum dilakukan Supervisi

\begin{tabular}{|c|c|c|c|c|c|c|c|c|c|c|c|c|c|}
\hline \multirow[t]{2}{*}{ NO } & \multirow{2}{*}{$\begin{array}{c}\text { Inisia } \\
1 \\
\text { Guru }\end{array}$} & & $\mathrm{K}$ & $\mathrm{R}$ & YA & $\mathrm{NC}$ & D & IPE & $\mathrm{RC}$ & LE & & \multirow[t]{2}{*}{$\begin{array}{c}\text { NIL } \\
\text { AI } \\
(\%)\end{array}$} & \multirow[t]{2}{*}{ Ket. } \\
\hline & & 1 & 2 & 3 & 4 & 5 & 6 & 7 & 8 & 9 & $\begin{array}{l}1 \\
0\end{array}$ & & \\
\hline 1 & A.H & 8 & 7 & 8 & 8 & 8 & 6 & 7 & 8 & 7 & 8 & 75 & $\mathrm{~T}$ \\
\hline 2 & MNT & 5 & 5 & 6 & 5 & 7 & 8 & 4 & 5 & 5 & 7 & 57 & $\mathrm{BT}$ \\
\hline 3 & DPD. & 7 & 6 & 7 & 6 & 7 & 6 & 6 & 8 & 6 & 5 & 64 & BT \\
\hline 4 & HTT. & 5 & 5 & 6 & 4 & 5 & 4 & 6 & 6 & 6 & 7 & 54 & BT \\
\hline 5 & DSW & 5 & 5 & 4 & 4 & 5 & 5 & 4 & 4 & 6 & 5 & 47 & $\mathrm{BT}$ \\
\hline 6 & DNI. & 8 & 7 & 8 & 7 & 7 & 8 & 7 & 7 & 8 & 8 & 75 & $\mathrm{~T}$ \\
\hline 7 & DEN & 5 & 4 & 4 & 4 & 5 & 4 & 4 & 4 & 6 & 5 & 45 & BT \\
\hline
\end{tabular}

El-Banat Vol. 9. No.2 (2019) 329 


\begin{tabular}{|c|l|c|c|c|c|c|c|c|c|c|c|c|c|}
\hline 8 & AZZ. & 7 & 6 & 7 & 6 & 7 & 6 & 6 & 8 & 6 & 5 & 64 & BT \\
\hline 9 & AST. & 8 & 8 & 8 & 8 & 7 & 8 & 7 & 7 & 8 & 7 & 76 & T \\
\hline 10 & NHS. & 5 & 6 & 5 & 6 & 7 & 6 & 6 & 8 & 6 & 5 & 60 & BT \\
\hline 11 & NSS & 5 & 6 & 5 & 6 & 5 & 6 & 6 & 6 & 6 & 5 & 56 & BT \\
\hline 12 & SIS. & 5 & 4 & 4 & 4 & 5 & 4 & 4 & 4 & 6 & 5 & 45 & BT \\
\hline 13 & $\begin{array}{l}\text { SLW } \\
.\end{array}$ & 5 & 5 & 4 & 4 & 5 & 5 & 4 & 4 & 6 & 5 & 47 & BT \\
\hline 14 & IMD. & 7 & 6 & 7 & 6 & 7 & 6 & 6 & 7 & 6 & 5 & 63 & BT \\
\hline 15 & $\begin{array}{l}\text { ABD } \\
.\end{array}$ & 8 & 8 & 6 & 7 & 8 & 7 & 7 & 8 & 8 & 8 & 75 & T \\
\hline 16 & $\begin{array}{l}\text { MH } \\
\text { B. }\end{array}$ & 7 & 6 & 7 & 6 & 7 & 6 & 6 & 7 & 6 & 5 & 63 & BT \\
\hline 17 & URH & 5 & 5 & 4 & 4 & 5 & 4 & 4 & 4 & 6 & 5 & 46 & BT \\
\hline 18 & $\begin{array}{l}\text { MM } \\
\text { S. }\end{array}$ & 6 & 6 & 7 & 5 & 8 & 4 & 3 & 7 & 5 & 7 & 58 & BT \\
\hline 19 & IDW. & 5 & 6 & 5 & 6 & 5 & 6 & 6 & 6 & 6 & 5 & 56 & BT \\
\hline 20 & HSH. & 6 & 6 & 7 & 5 & 8 & 4 & 3 & 7 & 5 & 7 & 58 & BT \\
\hline 21 & SYS. & 5 & 5 & 6 & 4 & 5 & 5 & 6 & 6 & 6 & 5 & 53 & BT \\
\hline 22 & FRD. & 4 & 6 & 6 & 6 & 6 & 6 & 7 & 6 & 6 & 5 & 58 & BT \\
\hline 23 & DSP. & 8 & 6 & 6 & 7 & 8 & 8 & 8 & 8 & 8 & 8 & 75 & T \\
\hline 24 & $\begin{array}{l}\text { MDL } \\
\text {. }\end{array}$ & 6 & 6 & 7 & 5 & 8 & 4 & 3 & 7 & 5 & 7 & 58 & BT \\
\hline 25 & $\begin{array}{l}\text { MH } \\
\text { A. }\end{array}$ & 8 & 7 & 8 & 8 & 8 & 5 & 8 & 8 & 8 & 8 & 76 & T \\
\hline 26 & SHS & 6 & 6 & 7 & 5 & 8 & 5 & 3 & 7 & 6 & 7 & 60 & BT \\
\hline 27 & $\begin{array}{l}\text { UMF } \\
.\end{array}$ & 7 & 7 & 7 & 5 & 6 & 7 & 5 & 5 & 5 & 5 & 59 & BT \\
\hline 28 & SQH. & 8 & 6 & 6 & 7 & 8 & 8 & 8 & 8 & 8 & 8 & 75 & T \\
\hline 29 & $\begin{array}{l}\text { AB } \\
\text { W }\end{array}$ & 6 & 6 & 7 & 5 & 8 & 4 & 3 & 7 & 5 & 7 & 58 & BT \\
\hline 30 & RHA & 4 & 6 & 4 & 6 & 4 & 6 & 7 & 5 & 5 & 5 & 52 & BT \\
\hline 31 & NHI & 6 & 7 & 8 & 8 & 7 & 8 & 7 & 8 & 8 & 8 & 75 & T \\
\hline 32 & SRT & 7 & 7 & 7 & 5 & 6 & 7 & 5 & 5 & 5 & 5 & 59 & BT \\
\hline 33 & $\begin{array}{l}\text { AM } \\
\text { D. }\end{array}$ & 5 & 4 & 4 & 4 & 5 & 4 & 4 & 4 & 6 & 5 & 45 & BT \\
\hline 34 & MBR & 5 & 4 & 4 & 4 & 5 & 4 & 4 & 4 & 6 & 5 & 45 & BT \\
\hline
\end{tabular}




\begin{tabular}{|c|l|c|c|c|c|c|c|c|c|c|c|c|c|}
\hline 35 & $\begin{array}{l}\text { LHK } \\
.\end{array}$ & 5 & 5 & 4 & 4 & 5 & 5 & 4 & 4 & 6 & 5 & 47 & BT \\
\hline 36 & SMD & 5 & 4 & 4 & 4 & 5 & 4 & 4 & 4 & 6 & 5 & 45 & BT \\
\hline 37 & ABL. & 4 & 6 & 6 & 6 & 6 & 6 & 7 & 5 & 6 & 6 & 58 & BT \\
\hline 38 & HFD & 8 & 8 & 7 & 7 & 8 & 7 & 7 & 8 & 8 & 7 & 75 & T \\
\hline 39 & SST. & 6 & 6 & 7 & 5 & 8 & 5 & 3 & 7 & 6 & 7 & 60 & BT \\
\hline & 6 & 5 & 6 & 5 & 6 & 5 & 5 & 6 & 6 & 6 & & \\
Prestasi Tia & 0 & 8 & 0 & 5 & 4 & 6 & 3 & 1 & 2 & 0. & $\mathbf{5 9 . 4}$ & \\
Soal (\%) &. &. &. &. &. &. &. &. &. & 8 & & \\
\hline
\end{tabular}

Keterangan: $\mathrm{T}=$ Tuntas, $\mathrm{BT}=$ Belum Tuntas

Berdasarkan Tabel 1 dapat dikemukakan sebagai berikut: 1) Rata-rata nilai kinerja guru dalam mengelola program pembelajaran menggunakan metode CTL sebelum dilakukan supervisi akademik pendekatan klinis $=59,4 \%$. Hal ini berarti secara umum guru-guru MTs. Muhammadiyah 1 Gresik masih belum mampu menggunakan metode CTL dalam mengelola program pembelajaran, belum memenuhi batas minimal nilai ketuntasan belajar kelas yang digunakan standar minimal dalam penelitian ini, yakni $75 \%$; 2) Terdapat 9 guru yang telah dinyatakan tuntas dalam menggunakan metode belajar CTL sebelum dilakukan supervisi, rata-rata nilai mereka $75 \% /$ lebih; 3) Terdapat 30 guru yang belum tuntas, rata-rata nilai mereka $<75 \%$, mereka itulah yang diidentifikasi memiliki masalah dalam menggunakan metode CTL dalam proses pembelajarannya. Ke 30 guru tersebut dijadikan subjek penelitian dalam penelitian ini. Hal ini berarti, peneliti memberikan supervisi akademik pendekatan klinis kepada 30 guru tersebut.

Meskipun guru-guru MTs. Muhammadiyah 1 Gresik menurut pengakuannya sudah sering menggunakan metode CTL dalam mengelola pembelajarannya, ternyata temuan penelitian menunjukkan dari 39 guru hanya 9 guru yang dinyatakan lulus (tuntas) menggunakan metode tersebut. Hasil pre-test menunjukkan rata-rata nilai ke 9 guru minimal $75 \%$. Sisanya, sebanyak 30 guru, dinyatakan masih belum menguasai metode CTL, nilai rata-rata mereka kurang dari $75 \%$.

Langkah identifikasi kemampuan guru tersebut memang dalam supervisi akademik pendekatan klinis seharusnya dilakukan oleh peneliti atau supervisor sebelum memberikan tindakan pembinaan (supervisi). Dengan demikian, program supervisi terfokus pada guru-guru yang diidentifikasi memiliki masalah dalam menggunakan metode CTL. Potensi efektivitas supervisi akan sangat tinggi jika pembinaan mengacu pada kondisi awal kemampuan guru. Berbeda halnya jika pembinaan 
tanpa diawali dengan identifikasi kemampuan--yang umumnya sering dilakukan oleh kepala sekolah dan atau pengawas kepada guru--, potensi untuk meningkatkan motivasi guru dalam belajar menggunakan metode CTL sangat rendah, khususnya bagi guru yang telah menguasai penggunaan metode CTL. Oleh karena itu guru-guru seperti itu potensial merasa bahwa pembinaan tersebut kurang bermanfaat. Respon negatif seperti itu akan mempengaruhi motivasi belajar bagi guru-guru yang memang belum mampu menguasai metode tersebut.

Memang idealnya dalam identifikasi melalui tes ditindaklanjuti dengan wawancara mendalam antara peneliti dengan setiap guru yang diidentifikasi kurang mampu. Melalui wawancara tersebut akan ditemukan sebab-sebab ketidakmampuan guru sehingga program supervisi akan lebih efektif karena merujuk pada sebab-sebab ketidakmampuan guru menggunakan metode CTL. Dalam penelitian ini mengingat keterbatasan waktu di satu sisi dan di sisi lain cukup banyaknya jumlah guru yang diidentifikasi kurang mampu berdasarkan hasil tes unjuk kerja, maka proses wawancara tersebut secara khusus belum dilakukan, namun demikian mengingat peneliti sangat dekat dengan guru-guru, peneliti telah mampu menilai kemampuan mereka dalam mengelola program pembelajaran, khususnya dalam menggunakan metode CTL.

Supervisi akademik pendekatan klinis hanya untuk guru yang membutuhkan (diidentifikasi membutuhkan) dalam penelitian ini sejalan dengan pendapat Pidarta, bahwa pendekatan klinis menurut kebanyakan diberlakukan bagi guru yang sangat lemah dalam melaksanakan tugasnya. ${ }^{15}$ Untuk memperbaiki performennya, dalam pendekatan klinis diperlukan serentetan supervisi hingga dapat memperbaiki satu persatu kelemahannya.

\section{Program Supervisi Akademik Pendekatan Klinis bagi Guru dalam Menggunakan Metode Pembelajaran CTL}

Untuk meningkatkan kemampuan guru dalam menggunakan metode CTL bagi guru-guru yang diidentifikasi belum mampu menggunakannya, diperlukan program supervisi akademik pendekatan klinis. Pokok-pokok program tersebut sebagai berikut: 1) Tujuan Supervisi. Guru dapat mengelola pembelajaran menggunakan metode CTL. Rinciannya, dapat: (a) membuat RPP menggunakan metode CTL;

${ }^{15}$ I Made Pidarta, Pemikiran tentang Supervisi Pendidikan (Jakarta: Bumi Aksara. 1995), 54. 
(b) mengimplementasikan RPP dalam pembelajaran secara tepat; (c) menyusun instrument tes ulangan harian (kuis); dan (d) menganalisis hasil belajar siswa; 2) Jenis Supervisi: Klinis; 3) Alokasi Waktu Supervisi: Dua hari, tiap hari mulai jam 09.00 WIB s/d jam 14.00 WIB dengan istirahat, sholat dan makan (ISHOMA) satu kali. Pertemuan untuk pre-test dan post-test tidak termasuk dalam jadwal ini. Rinciannya sebagai berikut.

Pertemuan Supervisi ke-1, Sabtu 30 Maret Maret 2019, dilakukan dengan tahap-tahap berikut ini: 1) Orientasi program supervisi (waktu 20 menit, jam 09.00-09.20 WIB); 2) Pembentukan kelompok (waktu 10 menit, jam 09.12-09.30 WIB). Berdasarkan hasil pre-test diperoleh 30 guru yang diidentifikasi masih belum tuntas dalam menggunakan metode CTL. Nilai pre test mereka $<75$. Guru-guru tersebut dipersilahkan membentuk kelompok menjadi 6 kelompok, setiap kelompok beranggotakan 5 guru; 3) Presentasi Kelas (waktu 2 jam, jam 09.30-11.30 WIB). Dalam hal ini, peneliti mempresentasikan cara menyusun Rencana Pelaksanaan Pembelajaran (RPP) menggunakan metode CTL. Materi : Pengembangan silabus pembelajaran pada mata pelajaran yang dibina masing-masing guru, meliputi identitas: sekolah, kelas, semester, tahun pelajaran, mata pelajaran, kompetensi dasar, dan jumlah jam pelajaran (menggunakan silabus yang sudah dimiliki guru), merumuskan indikator keberhasilan pembelajaran. Untuk ini harus dikemukakan unjuk kerja siswa setelah pembelajaran berakhir berdasarkan kompetensi dasar yang dibahas, merumuskan tujuan pembelajaran, merumuskan materi pokok yang dibahas, menetapkan metode pembelajaran yang digunakan, sumber dan media pembelajaran, langkah-langkah pembelajaran pada setiap pertemuan. Untuk ini harus memperhatikan prinsip-prinsip penggunaan metode CTL, yakni belajar secara kelompok, konstruktivisme (mengkonstruksi ide, pengetahuan untuk memperoleh pengetahuan baru) inquiri (menemukan), pembiasaan bertanya, masyarakat belajar, pemodelan (modelling), refleksi (reflection), penilaian yang orsinal (authentic assessment), dan teknik evaluasi hasil pembelajaran selama maupun setelah pembelajaran kompetensi dasar ini selesai. Evaluasi dapat dilakukan dengan mengevaluasi tugas-tugas, aktivitas belajar siswa dalam diskusi kelompok, dan keberhasilan siswa dalam mengerjakan ulangan harian (authentic assessment).

Pada tahap selanjutnya, peneliti mempresentasikan pelaksanaan pembelajaran di kelas disertai dengan modelling implementasi prinsipprinsip pembelajaran CTL. Ringkasan materi sebagai berikut: 1) Pelaksanaan pembelajaran di kelas harus sesuai langkah-langkah pembelajaran yang telah direncanakan dalam RPP, baik dalam 
mengkondisi siswa untuk belajar secara kelompok, mengkonstruksi ide pengetahuan yang telah dimiliki siswa untuk menjadi pengetahuan baru bagi diri siswa (konstruksivism), inquiri (menemukan jawaban atas permasalahan yang diajukan guru maupun teman-teman dalam diskusi kelompok), pembiasaan bertanya, masyarakat belajar (pembiasaan sharing pengetahuan), pemodelan (modelling), refleksi (reflection), maupun dalam penilaian yang orsinal (authentic assessment), baik penilaian proses maupun hasil belajar; 2) Intervensi guru sedapatnya terfokus pada upaya mengkondisikan siswa untuk belajar sesuai prinsipprinsip metode CTL sebagaimana telah dikemukakan. Penyampaian materi sedapatnya dilakukan seminimal mungkin karena kegiatan tersebut tidak dibenarkan dalam penggunaan metode CTL; 3) Istirahat, Sholat, dan Makan (ISHOMA) (1 jam, jam 11.30-13.30 WIB.); 4) Diskusi kelompok (waktu 1 jam, jam 13.30-14.30 WIB). Guru yang sudah terbagi ke dalam 6 kelompok mendiskusikan materi pembinaan peneliti sekaligus mengerjakan tugas-tugas yang ditugaskan peneliti, sementara peneliti memberikan pembinaan jika guru membutuhkannya. Setiap kelompok meresum hasil diskusi; 5) Diskusi Kelas (waktu 1 jam, jam 14.30-15.30 WIB). Masing-masing juru bicara kelompok mempresentasikan hasil diskusi kelompok di depan kelompok lainnya dalam satu kelas secara bergantian. Setiap kelompok diberi waktu 8 menit. Ketika satu kelompok presentasi, kelima kelompok lainnya dapat mengajukan pertanyaan dan kelompok penyaji memberikan jawaban. Demikian seterusnya sampai keenam kelompok mempresentasikan hasil diskusi kelompoknya di depan kelas; 6) Refleksi dan menutup pertemuan ke-1 (30 menit, jam 15.30-16.00 WIB.). Peneliti memberi refleksi proses supervisi hari pertama dan meresum materi supervisi, menyampaikan agenda pertemuan ke-2, kemudian menutup pertemuan ke1.

Pertemuan Supervisi ke-2 (Sabtu, 6 April 2019). Dalam pertemuan ini dilakukan beberapa tahap, di antaranya: 1) Orientasi program supervisi pertemuan ke-2 (20 menit, jam 09.00-09.20 WIB). 2) Pembentukan kelompok (waktu 10 menit, jam 09.12-09.30 WIB). Mekanisme pembentukan kelompok sama dengan pertemuan 1 . Pengelompokan guru pada pertemuan ke-1 tidak digunakan lagi. Hal ini dimaksudkan agar guru mendapat pengalaman langsung belajar dalam kelompok yang berbeda-beda. Pengalaman ini akan diwariskan pada siswa pada saat pembelajaran sesungguhnya agar kompetensi sosial siswa meningkat dan motivasi belajar juga meningkat. 3) Presentasi Kelas (waktu 2 jam, jam 09.30-11.30 WIB.), kegiatan: Pertama, peneliti mempresentasikan Instrumen evaluasi hasil belajar, meliputi: Instrumen evaluasi dalam metode CTL dinamakan penilaian yang orsinal. Evaluasi 
dilakukan baik dalam proses pembelajaran maupun akhir pembelajaran. Evaluasi proses misalnya dengan pemberian tugas-tugas, mengamati aktivitas belajar siswa dalam diskusi kelompok, dan evaluasi hasil berupa evaluasi dalam bentuk ulangan harian, penyusunan ulangan harian harus mengacu pada indikator dan tujuan pembelajaran. Jumlah butir pertanyaan harus mewakili seluruh materi pembelajaran. Selanjutnya, setelah dilakukan evaluasi/ulangan harian, perlu dibuat rekap nilai siswa dalam tabel rekapitulasi nilai hasil ulangan harian.

Kedua, peneliti mempresentasikan cara analisis tingkat ketuntasan belajar siswa. Di antara materinya sebagai berikut: Untuk menganalisis tingkat ketuntasan belajar siswa hendaknya menggunakan tabel rekapitulasi hasil ulangan harian. Berdasarkan tabel tersebut dapat diketahui nilai rata-rata kelas, jumlah siswa yang tuntas dan belum tuntas belajarnya, jumlah butir yang belum tuntas. Dengan demikian, guru dapat memberikan remedi pada siswa yang belum tuntas dan pada bidang materi yang belum dikuasai siswa dengan mudah. Ketiga, diskusi kelompok (waktu 1 jam, jam 13.30-14.30 WIB). Masing-masing kelompok mendiskusikan materi pembinaan Peneliti sekaligus mengerjakan tugas-tugas yang ditugaskan Peneliti, sementara Peneliti memberikan pembinaan jika guru membutuhkannya. Setiap kelompok meresum hasil diskusi untuk persiapan diskusi kelas.

Keempat, diskusi Kelas (waktu 1 jam, jam 14.30-15.30 WIB). Masing-masing juru bicara kelompok mempresentasikan hasil diskusi kelompok di depan kelompok lainnya dalam satu kelas secara bergantian. Setiap kelompok diberi waktu 10 menit. Ketika satu kelompok presentasi, kelima kelompok lainnya dapat mengajukan pertanyaan dan kelompok penyaji memberikan jawaban. Demikian seterusnya sampai keenam kelompok mempresentasikan hasil diskusi kelompoknya di depan kelas pada pertemuan ke-2 ini. Kelima, refleksi dan Menutup Pertemuan ke-2 (waktu 30 menit, jam 15.30-16.00 WIB). Peneliti memberi refleksi proses pembelajaran pada pertemuan ke-2, meresum materi supervisi, dan menyampaikan agenda bahwa pada pertemuan berikutnya dilakukan posttest. Untuk post-test ini guru harus membuat RPP untuk satu pertemuan dengan metode CTL. Bidang studi terserah masing-masing guru. Sebelum praktek mengajar sesungguhnya menggunakan metode CTL, guru menyerahkan RPP dan instrumen evaluasi kepada peneliti. Setelah informasi post-test jelas, kemudian Peneliti menutup pertemuan ke-2.

Dalam penelitian ini, materi supervisi diklasifikasi menjadi 4, yakni supervisi (pembinaan) dalam menyusun RPP, pembinaan dalam menyusun instrumen evaluasi hasil belajar, pembinaan dalam melaksanakan prosedur pembelajaran, dan pembinaan dalam 
menganalisis hasil evaluasi. Untuk materi supervisi menyusun RPP menggunakan metode CTL dijelaskan tahapan menyusun RPP, meliputi analisis atas silabus pembelajaran untuk mengetahui ruang lingkup materi, indikator dan tujuan pembelajaran, serta alokasi waktu pembelajaran. Tahapan ini harus dilakukan guru agar RPP yang disusunnya terintegrasi dengan program semester guru dan program tahunan guru serta sekolah/madrasah.

Dalam menyusun tahapan proses pembelajaran juga dijelaskan prosedur pembelajaran dengan metode CTL, meliputi presentasi pokokpokok materi pelajaran oleh guru, pembentukan kelompok kecil, diskusi kelompok, diskusi kelas, ulangan harian, analisis hasil ulangan harian hingga ditemukan tingkat ketuntasan masing-masing siswa dan rata-rata nilai tiap kelompok, serta pemberian hadiah bagi kelompok dengan ratarata nilai tertinggi.

Program supervisi yang dikembangkan dalam studi ini telah sesuai dengan prinsip-prinsip dan langkah-langkah penggunaan metode CTL yang disarankan Trianto $^{16}$ dan Muslich $^{17}$, yakni konstruktivisme (Constructivism), menemukan (Inquiry), bertanya (Questioning) masyarakat belajar (Learning Community), pemodelan (Modeling), refleksi (Reflection) dan penilaian yang sebenarnya (Authentic Assessment). Sebuah kelas dikatakan menggunakan pendekatan CTL jika menerapkan ketujuh komponen tersebut dalam pembelajarannya. Penerapan CTL dalam kelas secara garis besar dilakukan dengan langkah sebagai berikut: (1) Mengembangkan pemikiran bahwa anak akan belajar lebih bermakna dengan cara bekerja sendiri, menemukan sendiri, dan mengkostruksi sendiri pengetahuan dan keterampilan barunya; (2) Melaksanakan sejauh mungkin kegiatan inkuiri untuk semua topic; (3) Mengembangkan sifat ingin tahu siswa dengan bertanya; (4) Menciptakan 'masyarakat belajar' (belajar dalam kelompokkelompok); (5) Menghadirkan 'model' sebagai contoh pembelajaran; (6) Melakukan refleksi di akhir pertemuan; (7) Melakukan penilaian yang sebenarnya dengan berbagai cara.

\section{Efektivitas Supervisi Akademik dalam Meningkatkan Kinerja Guru Menggunakan Metode CTL}

Untuk mengetahui efektivitas supervisi akademik pendekatan klinis, maka dilakukan evaluasi kinerja guru pasca supervisi (pos-test). Post-test dalam studi ini pada prinsipnya merupakan evaluasi

16 Trianto, Mendesain Model Pembelajaran Inovatif Progresif, 107-108.

${ }^{17}$ Muslich, Pendidikan Karakter, 44. 
kemampuan guru dalam: (1) membuat RPP satu kompetensi dasar menggunakan metode pembelajaran CTL; (2) membuat instrumen evaluasi hasil belajar untuk mengetahui tingkat ketuntasan belajar siswa; (3) melaksanakan RPP dalam pembelajaran di kelas sesungguhnya sesuai jadwal pelajaran; dan (4) kemampuan menganalisis tingkat ketuntasan belajar siswa dengan Standar Ketuntasan Mengajar $(\mathrm{SKM})=75$. Alokasi waktu seluruhnya mulai pembelajaran, pelaksanaan kuis (ulangan harian), dan analisis tingkat ketuntasan belajar siswa seluruhnya dilakukan selama 2 minggu. Hal ini dimaksudkan untuk memberi kesempatan bagi MTs. yang jumlah peserta supervisinya cukup banyak. Hasil pos-test dapat dibaca pada Tabel 2.

Tabel 2.

Kinerja Guru dalam Menggunakan Metode CTL Setelah Supervisi

\begin{tabular}{|c|c|c|c|c|}
\hline No. & $\begin{array}{c}\text { Nama Inisial } \\
\text { Guru }\end{array}$ & $\begin{array}{c}\text { Jumlah } \\
\text { Skor }\end{array}$ & $\begin{array}{c}\text { Ketercapaian } \\
\%\end{array}$ & Ketuntasan \\
\hline 1 & MNT. & 83 & 83 & Tuntas \\
\hline 2 & DPD. & 71 & 71 & Belum Tuntas \\
\hline 3 & HTT. & 78 & 78 & Tuntas \\
\hline 4 & DSW. & 80 & 80 & Tuntas \\
\hline 5 & DEN & 78 & 78 & Tuntas \\
\hline 6 & AZZ. & 79 & 79 & Tuntas \\
\hline 7 & NHS. & 78 & 78 & Tuntas \\
\hline 8 & NSS & 79 & 79 & Tuntas \\
\hline 9 & SIS. & 80 & 80 & Tuntas \\
\hline 10 & SLW. & 76 & 76 & Tuntas \\
\hline 11 & IMD. & 70 & 70 & Belum Tuntas \\
\hline 12 & MHB. & 77 & 77 & Tuntas \\
\hline 13 & URH & 76 & 76 & Tuntas \\
\hline 14 & MMS. & 76 & 76 & Tuntas \\
\hline 15 & IDW. & 76 & 76 & Tuntas \\
\hline 16 & HSH. & 76 & 76 & Tuntas \\
\hline
\end{tabular}




\begin{tabular}{|l|c|c|c|c|}
\hline 17 & SYS. & 77 & 77 & Tuntas \\
\hline 18 & FRD. & 76 & 76 & Tuntas \\
\hline 19 & SHS & 77 & 77 & Tuntas \\
\hline 20 & UMF. & 76 & 76 & Tuntas \\
\hline 21 & MDL. & 78 & 78 & Tuntas \\
\hline 22 & ABW & 78 & 78 & Tuntas \\
\hline 23 & RHA. & 76 & 76 & Tuntas \\
\hline 24 & SRT & 79 & 79 & Tuntas \\
\hline 25 & AMD. & 78 & 78 & Tuntas \\
\hline 26 & MBR & 77 & 77 & Tuntas \\
\hline 27 & LHK. & 76 & 76 & Tuntas \\
\hline 28 & SMD. & 78 & 78 & Tuntas \\
\hline 29 & ABL. & 76 & 76 & Tuntas \\
\hline 30 & SST. & 78 & 78 & Tuntas \\
\hline & Rata-rata Nilai & $\mathbf{7 7 . 1}$ & & \\
\hline
\end{tabular}

Berdasarkan Tabel 2, dapat dijelaskan sebagai berikut: Pertama, rata-rata nilai kinerja guru dalam mengelola program pembelajaran menggunakan metode CTL setelah dilakukan supervisi akademik pendekatan klinis $=77,1 \%$. Hal ini berarti setelah dilakukan supervisi akademik pendekatan klinis secara umum guru-guru MTs. Muhammadiyah 1 Gresik telah mampu menggunakan metode CTL dalam mengelola program pembelajarannya, rata-rata nilai sudah melebihi batas minimum ketuntasan belajar kelas, yakni nilai $75 \%$. Kedua, terdapat 28 guru dari 30 guru yang telah dinyatakan tuntas dalam menggunakan metode belajar CTL setelah dilakukan supervisi akademik pendekatan klinis, rata-rata nilai mereka mencapai 75\%/lebih. Oleh karena itu dapat disimpulkan, bahwa supervisi akademik pendekatan klinis dalam penelitian ini dapat diklasifikasi cukup efektif. Jumlah guru yang telah menuntaskan pembelajaran menggunakan metode CTL mencapai 28 orang dari 30 guru, yang berarti mencapai $93.3 \%$, melebihi batas minimal keefektifan, yakni nilai $75 \%$. Ketiga, terdapat dua guru yang belum 
tuntas, rata-rata nilai $<75 \%$, Ia memerlukan perlakuan khusus dari peneliti dan kepala madrasah sebagai supervisor untuk program tindak lanjut supervisi akademik pendekatan klinis ini.

Temuan penelitian menunjukkan bahwa rata-rata nilai kinerja guru dalam mengelola program pembelajaran menggunakan metode CTL setelah dilakukan supervisi akademik pendekatan klinis $=77,1 \%$. Hal ini berarti setelah dilakukan supervisi akademik pendekatan klinis, secara umum guru-guru MTs. Muhammadiyah 1 Gresik telah mampu menggunakan metode CTL dalam mengelola program pembelajarannya, rata-rata nilai sudah melebihi batas minimum ketuntasan belajar kelas, yakni nilai $75 \%$. Terdapat 28 guru dari 30 guru $(93,3 \%)$ yang dibina oleh pengawas dinyatakan telah tuntas dalam menggunakan metode belajar CTL.

Standar ketuntasan belajar yang digunakan dalam penelitian ini sebesar $75 \%$ idealnya masih kurang memadai apabila merujuk pada standar ketuntasan ideal menurut Block $^{18}$ yang memberikan batas minimal ketuntasan belajar setiap $80 \%$. Namun demikian, kiranya KKM $75 \%$ akan dapat ditingkatkan guru seiring dengan adanya kebijakan kepala MTs. Muhammadiyah 1 Gresik yang menuntut guru untuk sesering mungkin menggunakan metode pembelajaran inovatif, termasuk metode CTL dalam proses pembelajaran. Dengan demikian, seringnya guru menggunakan metode CTL akan dapat menambah tingkat ketuntasan guru dalam menggunakan metode tersebut. Semakin sering guru menggunakan metode CTL, akan semakin sempurna, demikian sebaliknya. Semakin sering guru membelajarkan siswa menggunakan metode CTL, maka pengetahuan yang didapat siswa akan semakin "melekat" di dalam pikiran siswa dan mudah diimplementasikan dalam kehidupan sehari-hari. Daya tahan ingatan terhadap hasil pembelajaran akan lebih lama dibanding hasil pembelajaran yang kurang mengedepankan kegunaannya dalam kehidupan sehari-hari. Disinilah pentingnya penggunaan metode CTL bagi proses dan hasil belajar peserta didik.

\section{Kesimpulan}

Pada bagian ini, penulis uraikan kesimpulan bahwa rata-rata nilai kinerja guru dalam mengelola program pembelajaran menggunakan metode CTL sebelum dilakukan supervisi akademik pendekatan klinis =

18 Departemen Pendidikan Nasional Dirjen Pendidikan Dasar dan Menengah, Manajemen Peningkatan Mutu Berbasis Sekolah (Jakarta: Depdiknas, 2003), 34. 
$59,4 \%$. Hal ini berarti secara umum guru-guru MTs. Muhammadiyah 1 Gresik masih belum mampu menggunakan metode CTL dalam mengelola program pembelajarannya, masih jauh dari batas minimal nilai ketuntasan belajar kelas, yakni $75 \%$. Terdapat 30 guru yang belum tuntas, rata-rata nilai mereka kurang dari $75 \%$, mereka itulah yang diidentifikasi memiliki masalah dalam menggunakan metode CTL dalam proses pembelajarannya dan ke 30 guru itulah yang dijadikan subjek penelitian dalam penelitian ini. Program supervisi akademik dengan pendekatan klinis untuk membantu guru meningkatkan kinerjanya dalam menggunakan metode CTL terdiri dari beberapa tahap sebagai berikut: 1) Perumusan tujuan supervise; 2) Menetapkan jenis dan metode supervise; 3) Menentukan alokasi waktu supervise; 4) Menetapkan pertemuan, yakni dua pertemuan ( 2 hari) pada setiap pertemuan dilakukan: Orientasi program supervisi, Pembentukan kelompok, Presentasi kelas tentang tentang substansi supervisi, Diskusi kelompok, Diskusi Kelas, Refleksi dan Menutup Pertemuan. Post-test dilakukan sebagai evaluasi kemampuan guru setelah supervsi dalam: (1) membuat RPP satu kompetensi dasar menggunakan metode pembelajaran CTL; (2) membuat instrumen evaluasi hasil belajar untuk mengetahui tingkat ketuntasan belajar siswa; (3) melaksanakan RPP dalam pembelajaran di kelas sesungguhnya; dan (4) kemampuan menganalisis tingkat ketuntasan belajar siswa dengan Standar Ketuntasan Mengajar $(\mathrm{SKM})=75$. Supervisi akademik dengan pendekatan klinis ini ternyata cukup efektif, hal ini ditandai dengan rata-rata nilai kinerja guru dalam mengelola program pembelajaran menggunakan metode CTL setelah dilakukan supervisi akademik dengan pendekatan klinis sebesar $77,1 \%$, yang berarti sudah melebihi batas minimum ketuntasan belajar kelas, yakni nilai $75 \%$. Selain itu, terdapat 28 guru dari 30 guru $(93,3 \%)$ yang telah dinyatakan tuntas dalam menggunakan metode belajar CTL dengan rata-rata nilai mencapai 75\%/lebih. Hal ini telah melebihi batas minimal jumlah guru yang tuntas dalam penelitian ini, yakni minimal $75 \%$ guru telah tuntas belajarnya.

\section{Daftar Rujukan}

Departemen Pendidikan Nasional Dirjen Pendidikan Dasar dan Menengah. Manajemen Peningkatan Mutu Berbasis Sekolah. Jakarta: Depdiknas, 2003.

Komalasari, Kokom. Pembelajaran Kontekstual Konsep dan Aplikasi. Bandung: Refika Aditama, 2010. 
Ma'ruf. "Problematika Guru dalam Implementasi Penilaian Autentik Pada Kurikulum 2013 di SD Al Muslim Waru Sidoarjo." Jurnal Pendidikan Dasar Nusantara, Vol. 5 (Juli 2019).

Muslich, Mansur. KTSP: Pembelajaran Berbasis Kompetensi dan Kontekstual. Jakarta: Bumi Aksara, 2009.

Pendidikan Karakter: Menjawab Tantangan Krisis Multidimensional. Jakarta: Bumi Aksara, 2011.

Pidarta, I Made. Pemikiran tentang Supervisi Pendidikan. Jakarta: Bumi Aksara, 1995.

Senge, P., Cambron-McCabe, N. Lucas, T., Smith, B., Dutton, J. and Kleiner, A. Schools That Learn. A Fifth Discipline Fieldbook for Educators, Parents, and Everyone Who Cares About Education. New York: Doubleday/Currency, 2000.

Sanjaya, Wina. Strategi Pembelajaran Berorientasi Standar Proses Pendidikan. Jakarta: Kencana Prenada Media Group, 2006.

Subijanto. "Profesi Guru Sebagai Profesi yang Menjanjikan Pasca Undang-undang Guru dan Dosen." Jurnal Pendidikan dan Kebudayaan, No. 67 (Juli 2007).

Suprijono, Agus. Cooperative Learning: Teori dan Aplikasi PAIKEM. Yogyakarta : Pustaka Pelajar, 2009.

Surdin. "The Effect of Contextual Teaching and Learning (CTL) Models on learning outcomes of Social Sciences of the material of forms the face of the earth on Class VII of Junior High School". International Journal of Education and Research, Vol. 6, No. 3 (March 2018).

Trianto. Mendesain Model Pembelajaran Inovatif Progresif. Surabaya: Kencana, 2009.

Zahera, Sy. "Pembinaan yang Dilakukan Kepala Sekolah dan Etos Kerja Guru Sekolah Dasar." Jurnal Ilmu Pendidikan. Vol. 5, No. 2 (Mei 1998).

Zahorik, John, A. Constructivist Teaching. Bloomingthon Indiana: PhiDelta Kappa Educational Foundation, 1995. 